\title{
Adverse effect of obesity on red cell membrane arachidonic and docosahexaenoic acids in gestational diabetes
}

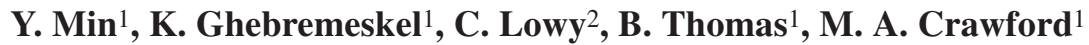 \\ ${ }^{1}$ Institute of Brain Chemistry and Human Nutrition, London Metropolitan University, London, UK \\ 2 Endocrine and Diabetic Day Centre, Guy's and St Thomas' Hospital Trust, London, UK
}

\section{Abstract}

Aims/hypothesis. Gestational diabetes is a metabolic disorder affecting $2-5 \%$ of women and is a predictor of obesity, Type 2 diabetes mellitus and cardiovascular disease. Insulin resistance, a characteristic of gestational diabetes and obesity, is correlated with the fatty acids profile of the red cell and skeletal muscle membranes. We investigated the plasma and red cell fatty acid status of gestational diabetes. The effect of obesity on membrane fatty acids was also examined.

Methods. Fasting blood obtained at diagnosis was analysed for the fatty acids in plasma choline phosphoglycerides and red cell choline and ethanolamine phosphoglycerides.

Results. There were reductions in arachidonic acid (controls $10.74 \pm 2.35$ vs gestational diabetes $8.35 \pm 3.49$, $p<0.01$ ) and docosahexaenoic acid (controls 6.31 \pm 2.67 vs gestational diabetes $3.25 \pm 2.00, p<0.0001)$ in the red cell choline phosphoglycerides in gestational diabetes. A similar pattern was found in the ethanol- amine phosphoglycerides. Moreover, the arachidonic and docosahexaenoic acids depletion in the red cell choline phosphoglycerides was much greater in overweight/obese gestational diabetes (arachidonic acid= $7.49 \pm 3.37$, docosahexaenoic acid $=2.98 \pm 2.18, p<0.01$ ) compared with lean gestational diabetes (arachidonic acid $=10.03 \pm 2.74$, docosahexaenoic acid $=4.18 \pm 1.42$ ).

Conclusion/interpretation. Apparently normal plasma choline phosphoglycerides fatty acids profile in the gestational diabetic women suggested that membrane lipid abnormality is associated specifically with perturbation in the membrane. The fact that the lipid abnormality is more pronounced in the outer leaflet of the membrane where most of receptor binding and enzyme activities take place might provide an explanation for the increased insulin resistance in gestational diabetes and obesity. [Diabetologia (2004) 47:75-81]

Keywords Gestational diabetes mellitus · obesity · red cells · choline phosphoglycerides · ethanolamine phosphoglycerides · arachidonic acid · docosahexaenoic acid
Pregnancy is associated with increased insulin resistance. In order to maintain normal carbohydrate toler-

Received: 7 May 2003 / Revised: 29 September 2003

Published online: 22 November 2003

C) Springer-Verlag 2003

Y. Min ( $)$, Institute of Brain Chemistry and Human Nutrition, London Metropolitan University, 166-220 Holloway Road, London, N7 8DB, UK

E-mail: y.min@londonmet.ac.uk

Abbreviations: AA, arachidonic acid; CPG, choline phosphoglycerides; DHA, docosahexaenoic acid; EPG, ethanolamine phosphoglycerides; FAME, fatty acid methyl esters; GDM, gestational diabetes mellitus. ance, both first and second phase insulin secretion increase [1]. A failure to respond to these changes leads to gestational diabetes mellitus (GDM) usually during the latter part of pregnancy [2]. In Western populations, GDM affects $2-5 \%$ of women, however the incidence rises considerably in certain ethnic communities where obesity is prevalent [3, 4]. Although GDM recedes after pregnancy, it is associated with an increased risk of obstetric complications and a predictor of obesity, Type 2 diabetes mellitus, and cardiovascular disease $[5,6,7]$ and thus a prodromal of the 'Metabolic Syndrome' [8].

The pathogenesis of insulin resistance in GDM remains unknown. However, defective pancreatic beta- 
cell function [1], impaired insulin receptor autophosphorylation [9], and CD36 deficit [10] have been proposed. Evidence is accumulating that the fatty acid composition of the membrane lipid is a critical cellular factor that influences both insulin secretion and its biological action [11, 12, 13, 14]. Arachidonic acid (20:4n-6, AA) and docosahexaenoic acid (22:6n-3, DHA), in particular, have been associated with insulin sensitivity [11]. Interestingly, insulin resistance was correlated with the fatty acids of the membrane choline phosphoglycerides (CPG) but not with those of ethanolamine phosphoglycerides (EPG) [15]; CPG and EPG are the predominant phospholipids of the outer and inner leaflet of the membrane lipid bilayer respectively [16].

One report [17] examined total red cell phospholipid fatty acid composition and found no difference between GDM and controls, but these women were studied at term and had all been treated to normalise their hyperglycaemia. Moreover, measuring total phospholipids obscures AA and DHA content by the sphingolipids with loss of sensitivity of the measurement.

Insulin resistance involves a loss of receptor and/or transporter efficiency in membrane. A change in membrane fatty acid profile would itself be expected to influence receptor function. Hence, we decided to study the membrane phospholipids fatty acids in control subjects and those women who developed diabetes during pregnancy. The role of pre-pregnancy BMI on membrane fatty acids was also investigated.

\section{Subjects and methods}

Subjects and sample collection. Women with singleton pregnancy were recruited during the 1 st trimester at the antenatal clinic of Guy's and St Thomas' Hospital. A 75 g OGTT was carried out between the 28th and 34th gestation week in all women. If the blood glucose concentration at 60 min was less than or equal to $8.0 \mathrm{mmol} / \mathrm{l}$ they were considered normal. If at $60 \mathrm{~min}$ the blood glucose concentration was greater than $8 \mathrm{mmol} / \mathrm{l}$ a second sample was taken at $120 \mathrm{~min}$. GDM was diagnosed if the blood glucose concentration at $120 \mathrm{~min}$ was equal to or greater than $9 \mathrm{mmol} / \mathrm{l}$-EASD criteria 1979 [18]. Of the subjects, 61 were normoglycaemic (control) and 53 were identified as GDM. Venous blood was collected in heparintreated tubes at the same time. Ethical approval was granted from The City Health Authority and Lambeth, Southwark and written informed consent was obtained from all participating women. This investigation was carried out in accordance with the principles of the Declaration of Helsinki as revised in 2000.

Fatty acid analysis. The fatty acids of the plasma and red cell phospholipids were analysed as described [19]. Briefly, the total plasma and red cell lipid was extracted by a known method [20] and phosphoglycerides classes were separated by thin-layer chromatography on silica gel plates by the use of the developing solvents: chloroform/methanol/water (60:30:4 by volume). Fatty acid methyl esters (FAME) were separated using a gasliquid chromatograph (HRGC MEGA 2 Series, Fisons Instruments, Milan, Italy) fitted with a BP20 capillary column (25 $\mathrm{m} \times 0.32 \mathrm{~mm}$ i.d., $0.25 \mu \mathrm{m}$ film). Hydrogen was used as a carrier gas and the injector, oven, and detector temperatures were 250,200 , and $280^{\circ} \mathrm{C}$, respectively. The FAME were identified by comparison of retension time with authentic standards. Peak areas were quantified by a computer chromatography data system (EZChrom Chromatography Data System, Scientific Software, San Ramon, Calif., USA). The fatty acids were expressed as a percentage of the total fatty acids.

Statistical analysis. The results are expressed as means \pm SD. Two-tailed unpaired $t$-test was used to compare the difference in plasma and red cell fatty acid composition between the control and GDM. The women were subdivided according to their pre-pregnancy BMI $(\leq 25$ or $>25)$. The effect of two factors, GDM and BMI, and its interaction on the red cell fatty acids was tested by two-way ANOVA. A post hoc test (GamesHowell test) for pair-wise comparisons was subsequently used to determine which group was different from each other. The data were analysed by the use of SPSS for Windows (version 10.0). A $p$ value of less than 0.05 was considered to be statistically significant.

\section{Results}

The mean $\mathrm{HbA}_{1 \mathrm{c}}$ was $5.9 \%$ in GDM, range 4.8 to 7.8 (Table 1). Women diagnosed as GDM were heavier prior to pregnancy and at the time of OGTT compared with control subjects. Subsets of 50 control subjects and 45 GDM were selected based on pre-pregnancy

Table 1. Characteristics of the study population

\begin{tabular}{lcl}
\hline & Control & GDM \\
\hline$n$ & 61 & 53 \\
Age (years) & $28.4 \pm 5.5$ & $30.6 \pm 4.6$ \\
Ethnicity & & \\
Caucasian & 24 & 12 \\
Afro-Caribbean/African & 17 & 31 \\
Asian & 9 & 5 \\
Others & 11 & 5 \\
Parity $(n)$ & & \\
$\quad 0$ & 24 & 15 \\
1 & 18 & 14 \\
$\geq 2$ & 6 & 17 \\
Unknown & 13 & 7
\end{tabular}

Pre-pregnancy BMI $\left(\mathrm{kg} / \mathrm{m}^{2}\right)^{\mathrm{a}}$

Mean

$29.0 \pm 4.0 \quad 32.9 \pm 5.9 \dagger$

Distribution ( $n$ )

$\leq 18.5$

$18.5-24.9$

$25-29.9$

$\geq 30$

Wt. at recruitment $(\mathrm{kg})$

Systolic BP (mm Hg)

Diastolic BP (mm Hg)

Serum glucose at $60 \mathrm{~min}(\mathrm{mmol} / \mathrm{l})$

Serum glucose at $120 \mathrm{~min}(\mathrm{mmol} / \mathrm{l})$

$\mathrm{HbA}_{1 \mathrm{c}}(\%)$

$30 \quad-$

$10 \quad 15$

$7 \quad 15$

$76.1 \pm 13.2 \quad 89.4 \pm 18.0^{*}$

$114.8 \pm 13.7 \quad 123.8 \pm 15.8$

$68.6 \pm 8.7 \quad 79.1 \pm 12.4$

$6.13 \pm 1.37 \quad 12.14 \pm 2.06$

$-\quad 10.9 \pm 2.4$

$4.6 \pm 0.62 \quad 5.9 \pm 0.77$

\footnotetext{
a The values were based on fifty controls and forty-five GDM

$*, \uparrow, \ddagger$ Significantly different from the controls at $p<0.05, p<0.01$, and $p<0.0001$ respectively
} 
BMI. Of the subjects, 11 control women and eight GDM were excluded from the analysis due to unknown pre-pregnancy weight. Of the control subjects, 34 were of normal weight $(\mathrm{BMI} \leq 25,68 \%)$ and 17 were overweight/obese (BMI>25, 34\%). In GDM, 15 had a BMI of less than or equal to $25(33.3 \%)$ and 30 had a BMI of greater than $25(66.7 \%)$.

The subjects were recruited regardless of their ethnic background, consequently the distribution of

Table 2. Plasma choline phosphoglycerides (CPG) fatty acid composition of the controls $(n=61)$ and GDM $(n=53)$

\begin{tabular}{lcc}
\hline Fatty acids $(\%)$ & \multicolumn{1}{l}{ Control } & \multicolumn{1}{l}{ GDM } \\
\hline $16: 0$ & $30.49 \pm 2.64$ & $31.84 \pm 2.19^{\dagger}$ \\
$18: 0$ & $10.19 \pm 1.02$ & $10.09 \pm 1.17$ \\
$16: 1$ & $0.81 \pm 0.28$ & $0.73 \pm 0.24$ \\
$18: 1$ & $11.42 \pm 1.67$ & $10.22 \pm 1.33 \ddagger$ \\
$18: 2 n-6$ & $23.39 \pm 2.75$ & $22.61 \pm 2.80$ \\
$20: 3 n-6$ & $3.44 \pm 0.71$ & $3.27 \pm 0.83$ \\
$20: 4 n-6$ & $8.50 \pm 1.58$ & $10.27 \pm 2.11^{\ddagger}$ \\
$22: 4 n-6$ & $0.29 \pm 0.12$ & $0.26 \pm 0.11$ \\
$22: 5 n-6$ & $0.46 \pm 0.25$ & $0.38 \pm 0.26$ \\
$18: 3 n-3$ & $0.35 \pm 0.14$ & $0.25 \pm 0.09 \ddagger$ \\
$20: 5 n-3$ & $0.80 \pm 0.73$ & $0.90 \pm 0.95$ \\
$22: 5 n-3$ & $0.62 \pm 0.22$ & $0.60 \pm 0.25$ \\
$22: 6 n-3$ & $4.53 \pm 1.70$ & $4.55 \pm 1.15$ \\
$20: 3 n-9$ & $0.21 \pm 0.10$ & $0.17 \pm 0.11$ \\
$\sum$ Saturates & $41.10 \pm 2.46$ & $42.33 \pm 2.11^{\dagger}$ \\
$\sum$ Monoenes & $12.60 \pm 1.83$ & $11.25 \pm 1.47 \ddagger$ \\
$\sum n-6$ & $36.70 \pm 2.85$ & $37.29 \pm 2.19$ \\
$\sum$ n-3 & $6.45 \pm 2.52$ & $6.37 \pm 1.75$ \\
\hline
\end{tabular}

$\dagger, \ddagger$ The values were significantly different from the corresponding level of controls at $p<0.01$ and $p<0.0001$ respectively ethnicity was different between the control and GDM subjects. However, the fatty acid profile of the plasma and red cell phosphoglycerides in the control AfroCaribbean/African subjects did not differ from the control Caucasian subjects. Also the same pattern was observed amongst the GDM.

The fatty acid composition of plasma CPG showed no consistent changes (Table 2). However, an increase in palmitic acid (16:0) and AA (20:4n-6) and a decrease in oleic acid (18:1) and DHA (22:6n-3) were found in the GDM compared with the control subjects. In contrast, the fatty acid composition in the red cell was markedly changed in the CPG and less so in the EPG (Table 3). The total saturated fatty acids were increased, whereas both n-6 and n-3 series were decreased in GDM compared with the control subjects. The most striking changes were in the $n-3$ series with a 50\% reduction in the GDM women.

Two-way ANOVA indicated that the effect of GDM and its interaction with BMI were significant on the red cell CPG AA, DHA, n- 6 and n-3 fatty acids (Table 4). Pair-wise comparison on the selected CPG fatty acids of interest was given in Table 5. In women with a BMI of less than or equal to 25, GDM had comparable fatty acid profile compared with that of the controls. On the contrary, the overweight/obese GDM showed a substantial reduction in AA and DHA in the red cell CPG compared with the overweight/obese control women. The loss of n- 6 and $n-3$ fatty acids was replaced by an increase in palmitic and oleic acids. Although the EPG fatty acids were not affected by BMI or GDM status, they followed a similar fatty acid distribution as the CPG (Table 6).

Table 3. Red cell (RBC) choline (CPG) and ethanolamine (EPG) phosphoglycerides fatty acid composition of the controls ( $n=61)$ and GDM $(n=53)$

\begin{tabular}{|c|c|c|c|c|}
\hline \multirow{2}{*}{$\begin{array}{l}\text { Fatty acids } \\
(\%)\end{array}$} & \multicolumn{2}{|l|}{ RBC CPG } & \multicolumn{2}{|l|}{ RBC EPG } \\
\hline & Control & GDM & Control & GDM \\
\hline 18:0 & $19.05 \pm 2.04$ & $17.63 \pm 2.84^{*}$ & $7.16 \pm 1.48$ & $7.82 \pm 2.11$ \\
\hline $16: 1$ & $0.48 \pm 0.23$ & $0.54 \pm 0.22$ & $0.47 \pm 0.19$ & $0.49 \pm 0.23$ \\
\hline $18: 1$ & $12.63 \pm 2.54$ & $15.29 \pm 3.25^{\dagger}$ & $18.14 \pm 3.10$ & $19.60 \pm 4.36$ \\
\hline $20: 4 n-6$ & $10.74 \pm 2.35$ & $8.35 \pm 3.49^{\dagger}$ & $14.97 \pm 2.19$ & $13.69 \pm 3.91$ \\
\hline $22: 4 n-6$ & $1.33 \pm 0.52$ & $0.83 \pm 0.49$ 末 & $4.20 \pm 1.29$ & $3.70 \pm 1.78$ \\
\hline $22: 5 n-6$ & $0.63 \pm 0.30$ & $0.60 \pm 0.51$ & $0.97 \pm 0.51$ & $0.95 \pm 0.95$ \\
\hline $18: 3 n-3$ & $0.18 \pm 0.08$ & $0.15 \pm 0.10^{*}$ & $0.21 \pm 0.14$ & $0.24 \pm 0.19^{*}$ \\
\hline $20: 5 n-3$ & $0.61 \pm 0.62$ & $0.36 \pm 0.23^{\ddagger}$ & $0.92 \pm 0.44$ & $0.79 \pm 0.52$ \\
\hline $22: 5 n-3$ & $1.64 \pm 0.75$ & $0.89 \pm 0.56^{\ddagger}$ & $2.98 \pm 0.75$ & $2.41 \pm 1.03^{\dagger}$ \\
\hline$\sum \mathrm{n}-6$ & $28.88 \pm 2.74$ & $25.71 \pm 6.28^{*}$ & $26.71 \pm 3.13$ & $24.66 \pm 5.91$ \\
\hline$\sum \mathrm{n}-3$ & $9.04 \pm 4.03$ & $4.71 \pm 2.67$ & $11.53 \pm 3.68$ & $9.49 \pm 4.01^{*}$ \\
\hline
\end{tabular}

$*, \uparrow, \$$ The values were significantly different from the corresponding level of controls at $p<0.05, p<0.01$, and $p<0.0001$ respectively 
Table 4. Effect of gestational diabetes, body mass and its interaction on the red cell AA, DHA, n-6 and n-3 fatty acids ${ }^{\mathrm{a}}$

\begin{tabular}{|c|c|c|c|c|c|c|}
\hline Phosphoglycerides & Fatty acids & BMI & Control & GDM & Two-way ANOVA & ( $p$ value $)$ \\
\hline \multirow[t]{9}{*}{ Choline } & \multirow[t]{2}{*}{$20: 4 n-6$} & $\leq 25$ & $9.72 \pm 1.99$ & $10.03 \pm 2.74$ & GDM & 0.019 \\
\hline & & $>25$ & $11.77 \pm 1.97$ & $7.49 \pm 3.37$ & BMI & 0.014 \\
\hline & \multirow[t]{3}{*}{$22: 6 n-3$} & $\leq 25$ & $5.31 \pm 1.79$ & $4.18 \pm 1.42$ & GDM & $<0.0001$ \\
\hline & & $>25$ & $7.15 \pm 2.38$ & $2.98 \pm 2.18$ & BMI & 0.36 \\
\hline & & & & & $\mathrm{GDM} \times \mathrm{BMI}$ & 0.011 \\
\hline & $\sum n-6$ & & & & $\mathrm{GDM} \times \mathrm{BMI}$ & 0.031 \\
\hline & \multirow[t]{3}{*}{$\sum n-3$} & $\leq 25$ & $7.66 \pm 2.71$ & $6.01 \pm 1.95$ & GDM & $<0.0001$ \\
\hline & & $>25$ & $10.14 \pm 4.00$ & $4.28 \pm 2.85$ & $\mathrm{BMI}$ & 0.042 \\
\hline & & & & & $\mathrm{GDM} \times \mathrm{BMI}$ & 0.013 \\
\hline \multirow[t]{8}{*}{ Ethanolamine } & $20: 4 n-6$ & $\leq 25$ & $14.96 \pm 2.47$ & $15.02 \pm 3.53$ & GDM & 0.274 \\
\hline & $22: 6 n-3$ & & & & $\mathrm{GDM} \times \mathrm{BMI}$ & 0.057 \\
\hline & \multirow[t]{3}{*}{$\sum n-6$} & $\leq 25$ & $26.58 \pm 3.47$ & $26.98 \pm 5.54$ & GDM & 0.197 \\
\hline & & $>25$ & $26.99 \pm 2.37$ & $23.57 \pm 5.86$ & BMI & 0.108 \\
\hline & & & & & $\mathrm{GDM} \times \mathrm{BMI}$ & 0.103 \\
\hline & \multirow[t]{3}{*}{$\sum n-3$} & $\leq 25$ & $11.00 \pm 3.96$ & $11.02 \pm 3.49$ & GDM & 0.088 \\
\hline & & $>25$ & $12.24 \pm 2.90$ & $8.94 \pm 4.34$ & BMI & 0.193 \\
\hline & & & & & $\mathrm{GDM} \times \mathrm{BMI}$ & 0.083 \\
\hline
\end{tabular}

a Data shown are the means \pm SD for Control $\leq 25(n=34)$, Control $>25(n=17)$, GDM $\leq 25(n=15)$, GDM $>25(n=30)$

Table 5. Red cell choline phosphoglycerides fatty acids of the controls and GDM in relation to BMI: Results of post hoc test

\begin{tabular}{|c|c|c|c|c|}
\hline \multirow[t]{2}{*}{ Fatty acids (\%) } & \multicolumn{2}{|l|}{$\mathrm{BMI} \leq 25$} & \multicolumn{2}{|l|}{$\mathrm{BMI}>25$} \\
\hline & $\begin{array}{l}\text { Control }^{\mathrm{a}} \\
(n=34)\end{array}$ & $\begin{array}{l}\mathrm{GDM}^{\mathrm{b}} \\
(n=15)\end{array}$ & $\begin{array}{l}\text { Control }^{c} \\
(n=17)\end{array}$ & $\begin{array}{l}\mathrm{GDM}^{\mathrm{d}} \\
(n=30)\end{array}$ \\
\hline $16: 0$ & $24.92 \pm 3.53^{\mathrm{b}, \mathrm{c}}$ & $28.17 \pm 4.66^{\mathrm{a}, \mathrm{d}}$ & $22.04 \pm 4.52^{\mathrm{a}}$ & $31.62 \pm 5.76^{b}$ \\
\hline 18:0 & $18.36 \pm 0.97 \mathrm{~b}, \mathrm{c}, \mathrm{d}$ & $17.74 \pm 4.02^{\mathrm{a}, \mathrm{c}, \mathrm{d}}$ & $19.51 \pm 2.01^{\mathrm{a}, \mathrm{b}, \mathrm{d}}$ & $17.72 \pm 2.49^{\mathrm{a}, \mathrm{b}, \mathrm{c}}$ \\
\hline $18: 1$ & $13.32 \pm 2.52^{\mathrm{b}, \mathrm{c}, \mathrm{d}}$ & $14.55 \pm 2.34^{\mathrm{a}, \mathrm{c}, \mathrm{d}}$ & $12.03 \pm 2.32^{\mathrm{a}, \mathrm{b}}$ & $15.52 \pm 3.50^{\mathrm{a}, \mathrm{b}}$ \\
\hline $20: 4 n-6$ & $9.72 \pm 1.99 \mathrm{~b}, \mathrm{c}, \mathrm{d}$ & $10.03 \pm 2.74^{\mathrm{a}, \mathrm{c}, \mathrm{d}}$ & $11.77 \pm 1.97 \mathrm{a}, \mathrm{b}$ & $7.49 \pm 3.37 \mathrm{a}, \mathrm{b}$ \\
\hline $22: 4 n-6$ & $1.15 \pm 0.34^{b, c}$ & $1.05 \pm 0.55^{\mathrm{a}, \mathrm{c}, \mathrm{d}}$ & $1.46 \pm 0.44^{\mathrm{a}, \mathrm{b}}$ & $0.74 \pm 0.42^{b}$ \\
\hline $22: 5 n-6$ & $0.58 \pm 0.27 \mathrm{~b}, \mathrm{c}, \mathrm{d}$ & $0.67 \pm 0.58^{\mathrm{a}, \mathrm{c}, \mathrm{d}}$ & $0.71 \pm 0.36^{\mathrm{a}, \mathrm{b}, \mathrm{d}}$ & $0.59 \pm 0.52^{\mathrm{a}, \mathrm{b}, \mathrm{c}}$ \\
\hline $18: 3 n-3$ & $0.17 \pm 0.09^{\mathrm{b}, \mathrm{c}, \mathrm{d}}$ & $0.16 \pm 0.06^{\mathrm{a}, \mathrm{c}, \mathrm{d}}$ & $0.19 \pm 0.05^{\mathrm{a}, \mathrm{b}, \mathrm{d}}$ & $0.15 \pm 0.12^{\mathrm{a}, \mathrm{b}, \mathrm{c}}$ \\
\hline $20: 5 n-3$ & $0.45 \pm 0.15^{\mathrm{b}, \mathrm{c}, \mathrm{d}}$ & $0.43 \pm 0.20^{\mathrm{a}, \mathrm{c}, \mathrm{d}}$ & $0.71 \pm 0.80^{\mathrm{a}, \mathrm{b}, \mathrm{d}}$ & $0.32 \pm 0.24 \mathrm{a}, \mathrm{b}, \mathrm{c}$ \\
\hline $22: 5 n-3$ & $1.36 \pm 0.47 \mathrm{~b}, \mathrm{c}$ & $1.14 \pm 0.50^{\mathrm{a}, \mathrm{c}, \mathrm{d}}$ & $1.76 \pm 0.78^{\mathrm{a}, \mathrm{b}}$ & $0.79 \pm 0.56^{b}$ \\
\hline$\sum n-3$ & $7.66 \pm 2.71^{b, c}$ & $6.01 \pm 1.95^{\mathrm{a}, \mathrm{c}, \mathrm{d}}$ & $10.14 \pm 4.00^{\mathrm{a}, \mathrm{b}}$ & $4.28 \pm 2.85^{b}$ \\
\hline
\end{tabular}

Means that do not share a superscript letter are significantly different at the 0.05 level

A heavier body mass, however, did not compromise the n-6 and n-3 fatty acid content in the red cell CPG of the control women. The relative percent of n- 6 and $n-3$ series tended to increase and was significant $(p=0.038)$ for AA in the overweight/obese controls in comparison with the lean control women.

\section{Discussion}

In this study we have shown that at diagnosis, women with GDM had reduced AA and DHA levels in the red cell CPG, the major phosphoglycerides of the outer leaflet of the membrane. A similar GDM-induced 
Table 6. Red cell ethanolamine phosphoglycerides fatty acids of the controls and GDM in relation to BMI

\begin{tabular}{|c|c|c|c|c|}
\hline \multirow[t]{2}{*}{ Fatty acids (\%) } & \multicolumn{2}{|l|}{$\mathrm{BMI} \leq 25$} & \multicolumn{2}{|l|}{$\mathrm{BMI}>25$} \\
\hline & $\begin{array}{l}\text { Control } \\
(n=34)\end{array}$ & $\begin{array}{l}\text { GDM } \\
(n=15)\end{array}$ & $\begin{array}{l}\text { Control } \\
(n=17)\end{array}$ & $\begin{array}{l}\text { GDM } \\
(n=30)\end{array}$ \\
\hline 16:0 & $17.93 \pm 3.42$ & $18.02 \pm 3.03$ & $17.32 \pm 3.21$ & $20.19 \pm 3.90$ \\
\hline 18:0 & $7.58 \pm 1.70$ & $7.13 \pm 1.24$ & $6.64 \pm 1.18$ & $7.96 \pm 2.39$ \\
\hline $18: 1$ & $18.53 \pm 3.48$ & $17.47 \pm 3.21$ & $17.87 \pm 2.47$ & $20.96 \pm 4.76$ \\
\hline $20: 4 n-6$ & $14.96 \pm 2.47$ & $15.02 \pm 3.53$ & $14.87 \pm 1.66$ & $13.02 \pm 4.25$ \\
\hline $22: 4 n-6$ & $3.85 \pm 1.23$ & $4.33 \pm 1.56$ & $4.63 \pm 1.33$ & $3.38 \pm 1.59$ \\
\hline $22: 5 n-6$ & $1.08 \pm 0.57$ & $1.07 \pm 1.05$ & $0.91 \pm 0.46$ & $0.95 \pm 0.99$ \\
\hline $18: 3 n-3$ & $0.19 \pm 0.09$ & $0.22 \pm 0.07$ & $0.24 \pm 0.20$ & $0.27 \pm 0.24$ \\
\hline $20: 5 n-3$ & $0.95 \pm 0.43$ & $0.86 \pm 0.44$ & $0.82 \pm 0.29$ & $0.73 \pm 0.57$ \\
\hline $22: 5 n-3$ & $2.90 \pm 0.79$ & $2.82 \pm 0.87$ & $3.05 \pm 0.59$ & $2.28 \pm 1.16$ \\
\hline$\sum n-3$ & $11.00 \pm 3.96$ & $11.02 \pm 3.49$ & $12.24 \pm 2.90$ & $8.94 \pm 4.34$ \\
\hline
\end{tabular}

effect was also apparent in the EPG. Interestingly, the unfavourable effect of a high pre-pregnancy BMI on the red cell AA and DHA was found only in the GDM women.

The red cell cannot alter fatty acid chain length or the degree of unsaturation or synthesise phospholipids de novo [21] thus red cell CPG would be expected to reflect diet and plasma lipids to some extent. However, this was not the case as the plasma fatty acids composition of the GDM was comparable to that of the control subjects. In fact, the plasma AA level was higher in the GDM. Following the diagnostic OGTT only the GDM women were interviewed by a dietician but they were not given any particular advice on n-3 and n-6 fats. Nutrient intake was obtained subsequent to the OGTT from a sub-sample of women (control=10, GDM=13) by using a weighed three-day diet diary. Foodbase2000, nutrition analysis software developed by our institute and validated [22, 23, 24] was used to analyse the food composition. The results gave no evidence of differences in the dietary $n-6$ and n-3 fatty acids intake between the two groups. Moreover, there was no biochemical indication of dietary linoleic (18:2n-6) and alpha-linolenic (18:3n-3) acids or DHA deficiency measured by Mead acid (20:3n-9) [25], the Mead acid/AA ratio [26, 27], and docosapentaenoic acid (22:5n-6) in the plasma and red cell CPG. In contrast, others [28, 29, 30] have shown that GDM have a different fat intake (more saturated fat and less polyunsaturated fat) compared with control subjects. Although we did not have pre-diagnosis dietary information for these women, the fact that the plasma CPG and triglycerides (data not shown) were similar in the two groups suggests that dietary fat played a minor role in determining membrane fatty acids in the GDM.
The biosynthesis of AA and DHA requires delta- 6 and delta-5 desaturase that are insulin dependent [31, $32,33]$. So far, there is no evidence that the activities of delta- 6 and delta-5 desaturase are impaired in GDM. However, it is conceivable that its function could be depressed as seen in Type 2 diabetes mellitus [34] and obesity [35]. Yet, we found no difference in the ratio of AA (20:4n-6)/dihomo-gamma-linolenic acid (20:3n-6) in the red cell CPG, an indirect measure for delta-5 desaturase activity. This suggests that the pathology of glucose intolerance is associated with the incorporation of AA and DHA into membrane phospholipids.

A further analysis revealed that high pre-pregnancy BMI in GDM exaggerated the membrane lipid perturbation while lean GDM women managed to retain AA and DHA levels despite their equivalent hyperglycaemia (based on the glycaemic values at OGTT). Obesity is associated with glucose intolerance and reduced DHA in the skeletal muscle and red cells total phospholipid [36, 37]. Therefore, the overweight/ obese control women were expected to follow a similar pattern to obese GDM. But unexpectedly, the overweight/obese control women had a higher AA and DHA compared with their leaner counterparts. We considered if it could be that the hyperglycaemia plays a pivotal role in determining membrane fatty acids. Although the glucose concentration at $120 \mathrm{~min}$ did not differ between overweight/obese and lean GDM women, the mean $\mathrm{HbA}_{1 \mathrm{c}}$ tended to be higher in overweight/obese $(5.9 \%)$ than lean $(5.6 \%)$ subjects. Thus glucose intolerance superimposed on obesity was associated with membrane lipid abnormality.

It is not clear whether the changes in membrane fatty acid composition alter the insulin action or the increased concentration of glucose and insulin leads to membrane lipid abnormality. There is clear evidence 
of altered insulin binding [38] and its action [39] as a result of modification of fatty acids in the membrane phospholipids. Conversely, one study [15] showed that insulin resistance induced by nicotinic acid administration resulted in changes in fatty acid composition of the CPG in the muscle. An alternative explanation for membrane lipid abnormality in GDM could be structural change in membrane protein. Hydrophobic matching thickness of lipid bilayer (i.e. lipid acylchain length) and integral membrane proteins have been proposed as a determinator of the coupling between lipid and membrane proteins [40]. Protein prefers to be associated with the lipid species that is hydrophobically best matched. If the membrane protein structure changes by extracellular forces such as peroxidation and glycosylation, its folding property will alter, thereby its lipid composition may have to change to match. Abnormal glucose transporters [41], decreased insulin receptor binding protein [42], $\mathrm{Ca}^{++}$ transmembrane movement [43], alteration of uncoupling and remodelling of actin [44, 45] are examples of altered membrane protein function depressed in diabetes and obesity.

The red cell membrane is essentially an example of plasma membrane. Compositionally it is very similar to the vascular endothelium. This similarity could derive from the fact that the endothelial cell has the highest plasma membrane/cytoplasm ratio of any cell in the body. It is therefore likely that if the red cell membrane is selectively affected in diabetes or obesity, the endothelium could also be affected. The expected consequences would be vascular dysfunction. A loss of AA and DHA would reduce liquidity and the liberal mechanical properties normal to active cell membranes. Such a defect in the endothelial membrane could create susceptibility to vascular dysfunction as experimentally demonstrated in rats [46, 47].

At diagnosis, GDM was associated with AA and DHA reduction and increased palmitic acid in the red cell phosphoglycerides. The combination of glucose intolerance and obesity had unfavourable effects on membrane AA and DHA contents in overweight/ obese GDM. The fact that the lipid abnormality was more pronounced in the outer leaflet of the membrane phospholipids, CPG where most of receptor binding and enzyme activities take place, might provide an explanation for the increased insulin resistance in GDM. It is conceivable that hyperglycaemia might cause the impairment in fatty acids incorporation into the red cell membrane. Or it could be that the genetically determined membrane protein causes reorganisation of lipid bilayer, subsequently affecting the structure or activities of membrane bound transporters or receptors.

Acknowledgements. The financial support of the Diabetes UK and President Club of The Mother and Child Foundation is gratefully acknowledged. We thank all the women who participated in the study and B. Offley-Shore for her assistance in recruiting the women, and collecting samples and clinical information.

\section{References}

1. Buchanan TA, Metzger BE, Freinkel N, Bergman RN (1990) Insulin sensitivity and B-cell responsiveness to glucose during late pregnancy in lean and moderately obese women with normal glucose tolerance or mild gestational diabetes. Am J Obstet Gynecol 162:1008-1014

2. Hollingsworth DR (1985) Maternal metabolism in normal pregnancy and pregnancy complicated by diabetes mellitus. Clin Obstet Gycol 28:457-472

3. Moses RG, Griffiths RD, McPherson S (1994) The incidence of gestational diabetes mellitus in the Illawarra area of New South Wales. Aust NZ J Obstet Gynaecol 34:425-427

4. Koukkou E, Taub N, Jackson P, Metcalfe G, Cameron M, Lowy C (1995) Difference in prevalence of gestational diabetes and perinatal outcome in an innercity multiethnic London population. Eur J Obstet Gynecol Reprod Biol 59:153-157

5. Barden TP, Knowles HC Jr (1981) Diagnosis of diabetes in pregnancy. Clin Obstet Gycol 24:3-19

6. O'Sullivan JB (1991) Diabetes mellitus after GDM. Diabetes 40:131-135

7. Verma A, Boney CM, Tucker R, Vohr BR (2002) Insulin resistance syndrome in women with prior history of gestational diabetes mellitus. J Clin Endocrinol Metab $87: 3227-3235$

8. Kendall DM, Harmel AP (2002) The metabolic syndrome, Type 2 diabetes, and cardiovascular disease: understanding the role of insulin resistance. Am J Manag Care 8:S635-S653

9. Friedman JE, Ishizuka T, Shao J, Huston L, Highman T, Catalano P (1999) Impaired glucose transport and insulin receptor tyrosine phosphorylation in skeletal muscle from obese women with gestational diabetes. Diabetes 48:18071814

10. Miyaoka K, Kuwasako T, Hirano K, Nozaki S, Yamashita S, Matsuzawa Y (2001) CD36 deficiency associated with insulin resistance. Lancet 357:686-687

11. Borkman M, Storlien LH, Pan DA, Jenkins AB, Chisholm DJ, Campbell LV (1993) The relation between insulin sensitivity and the fatty acid composition of skeletal-muscle phospholipids. N Engl J Med 328:238-244

12. Clandinin MT, Garg ML, Parrott A, Aerde J van, Hervada A, Lien E (1992) Addition of long-chain polyunsaturated fatty acids to formula for very low birth weight infants. Lipids 27:896-900

13. Pan DA, Hulbert AJ, Storlien LH (1994) Dietary fats, membrane phospholipids and obesity. J Nutr 124:15551565

14. Tong P, Thomas T, Berrish T, et al. (1995) Cell membrane dynamics and insulin resistance in non-insulin-dependent diabetes mellitus. Lancet 345:357-358

15. Clore JN, Harris PA, Li J, et al. (2000) Changes in phosphatidylcholine fatty acid composition are associated with altered skeletal muscle insulin responsiveness in normal man. Metabolism 49:232-238

16. Roelofsen B, Zwaal RFA (1976) The use of phospholipases in the determination of asymmetric phospholipid distribution in membranes. Meth Membr Biol 7:147-177

17. Wijendran V, Bendel RB, Couch SC, et al. (1999) Maternal plasma phospholipid polyunsaturated fatty acids in pregnancy with and without gestational diabetes mellitus: relations with maternal factors. Am J Clin Nutr 70:53-61

18. National Diabetes Data Group (1979) Classification and diagnosis of diabetes mellitus and other categories of glucose intolerance. Diabetes 28:1039-1057 
19. Min Y, Ghebremeskel K, Crawford MA, et al. (2000) Pregnancy reduces arachidonic and docosahexaenoic in plasma triacylglycerols of Korean women. Int J Vitam Nutr Res 70:70-75

20. Folch J, Lees M, Sloanestanley HS (1957) A simple method for the isolation and purification of total lipids from animal tissues. J Biol Chem 54:497-509

21. Lubin B, Kuypers FA, Chiu D (1989) Red cell membrane lipid dynamics. Proceeding of The Red Cell:Seventh Ann Arbor Conference. Alan R. Liss, pp 507-524

22. Doyle W, Crawford MA, Laurence BM (1982) Dietary survey during pregnancy in a low socioeconomic group. J Hum Nutr 36A:95-106

23. Doyle W, Crawford MA, Wynn AHA, Wynn SW (1990) The association between maternal diet and birth dimensions. J Nutr Med 1:9-17

24. Doyle W, Wynn AHA, Crawford MA, Wynn SW (1992) Nutritional counseling and supplementation in the second and third trimester of pregnancy, a study in a London population. J Nutr Med 3:249-256

25. Dhopeshwarkar GA, Mead JFJ (1961) Role of oleic acid in the metabolism of essential fatty acids. J Am Oil Chem Soc 38:297-301

26. Fiennes RNTW, Sinclair A, Crawford MA (1973) Essential fatty acid studies in primates. Linolnic acid requirements of Capuchins. J Med Primate 2:155-169

27. Holman RT, Johnson S (1981) Changes in essential fatty acid profile of serum phospholipids in human disease. Prog Lipid Res 20:67-73

28. Moses RG, Shand JL, Tapsell LC (1997) The recurrence of gestational diabetes: Could dietary differences in fat intake be an explanation? Diabetes Care 20:1647-1650

29. Wang Y, Storlien LH, Jenkins AB, et al. (2000) Dietary variables and glucose tolerance in pregnancy. Diabetes Care 23:460-464

30. Bo S, Menato G, Lezo A, et al. (2001) Dietary fat and gestational hyperglycaemia. Diabetologia 44:972-978

31. Shin CS, Lee MK, Park KS, et al. (1995) Insulin restores fatty acid composition in liver microsomes than erythrocyte membranes in streptozotocin-induced diabetic rats. Diabetes Res Clin Pract 29:93-98

32. Melin T, Nilsson A (1997) Delta-6-desaturase and delta5-desaturase in human Hep G2 cells are both fatty acid interconversion rate limiting and are upregulated under essential fatty acid deficient conditions. Prostaglandins Leukot Essent Fatty Acids 56:437-442

33. Brenner RR (2003) Hormonal modulation of delta 6 and delta 5 desaturases: case of diabetes. Prostaglandins Leukot Essent Fatty Acids 68:151-162

34. Doormaal JJ van, Muskiet FA, Ballegooie E van, Sluiter WJ, Doorenbos H (1984) The plasma and erythrocyte fatty acid composition of poorly controlled, insulin-dependent (type I) diabetic patients and the effect of improved metabolic control. Clin Chim Acta 144:203-212
35. Pan DA, Lillioja S, Milner MR, et al. (1995) Skeletal muscle membrane lipid composition is related to adiposity and insulin action. J Clin Invest 96:2802-2808

36. Storlien LH, Pan DA, Kriketos AD, et al. (1996) Skeletal muscle membrane lipids and insulin resistance. Lipids 31:S261-S265

37. Baur LA, O'Connor J, Pan DA, Storlien LH (1999) Relationships between maternal risk of insulin resistance and the child's muscle membrane fatty acid composition. Diabetes 48:112-116

38. Field CJ, Ryan EA, Thomson AB, Clandinin MT (1988) Dietary fat and the diabetic state alter insulin binding and the fatty acyl composition of the adipocyte plasma membrane. Biochem J 253:417-424

39. Storlien LH, Jenkins AB, Chisholm DJ, Pascoe WE, Khouri S, Kraegen EW (1991) Influence of dietary fat composition on development of insulin resistance in rats: Relationship to muscle triglyceride and $\omega-3$ fatty acids in muscle phospholipid. Diabetes 40:280-289

40. Dumas F, Sperotto MM, Lebrun MC, Tocanne JF, Mouritsen OG (1997) Molecular sorting of lipids by bacteriorhodopsin in dilauroylphosphatidylcholine/distearoylphosphatidylcholine lipid bilayers. Biophys J 73:1940 1953

41. Hu X, Peng F, Zhou H, Zhang Z, Cheng W, Feng H (2000) The abnormality of glucose transporter in the erythrocyte membrane of Chinese Type 2 diabetic patients. Biochem Biophys Acta 1466:306-314

42. Damm P, Handberg A, Kuhl C, Beck-Nielsen H, MolstedPedersen L (1993) Insulin receptor binding and tyrosine kinase activity in skeletal muscle from normal pregnant women and women with gestational diabetes. Obstet Gynecol 82:251-259

43. Balasubramanyam M, Balaji RA, Subashini B, Mohan V (2001) Evidence for mechanistic alterations of $\mathrm{Ca} 2+$ homeostasis in Type 2 diabetes mellitus. Int J Exp Diabetes Res 1:275-287

44. Dalgaard LT, Pedersen O (2001) Uncoupling proteins: functional characteristics and role in the pathogenesis of obesity and Type II diabetes. Diabetologia 44:946965

45. Tong P, Khayat ZA, Huang C, Patel N, Ueyama A, Klip A (2001) Insulin-induced cortical actin remodeling promotes GLUT4 insertion at muscle cell membrane ruffles. J Clin Invest 108:371-381

46. Koukkou E, Ghosh P, Lowy C, Poston L (1998) Offspring of normal and diabetic rats fed saturated fat in pregnancy demonstrate vascular dysfunction. Circulation 98:28992904

47. Ghosh P, Bitsanis D, Ghebremeskel K, Crawford MA, Poston L (2001) Abnormal aortic fatty acid composition and small artery function in offspring of rats fed a high fat diet in pregnancy. J Physiol 533:822 